\title{
From everyday to scientific (mathematical) concepts: A Vygotskian interpretation of a young child's speech
}

\author{
Marie Therese Farrugia, University of Malta (Malta)
}

From everyday to scientific (mathematical) concepts: A Vygotskian interpretation of a young child's speech

\begin{abstract}
In Early Childhood settings, children are considered to learn through play. In this paper I report on a case-study of a four-year-old boy playing with loose parts. As he played, I interacted with him by commenting and asking questions. My aim was to include mathematics in his play. My analysis involved a micro-examination of the interaction to trace the child's language over the sessions. The theoretical framework employed was Vygotsky's distinction between everyday and scientific concepts and his theory of play. I noted that the interactive contexts supported the child to use certain words in association with others. In particular, he started to link the words big/small with numbers, thus quantifying size, which is the foundation of measurement. In line with the importance afforded to speech by Vygotsky, I was able to trace the role played by words in the child's progression from everyday (play) concepts to scientific (mathematical) concepts.
\end{abstract}

Keywords. Early childhood mathematics; learning through play; everyday and scientific concepts; language and mathematics; Vygotsksy.

De los conceptos cotidianos a los científicos (matemáticos): Una interpretación vygotskiana del habla de un niño

\section{Resumen}

En los entornos de las primeras edades, se considera que los niños aprenden a través del juego. En este artículo, documento un estudio de caso de un niño de cuatro años jugando con 'objetos sueltos'. A medida que jugaba, interactúe con él mediante comentarios y preguntas. My propósito era incluir matemáticas en su juego. El análisis involucró un micro examen de la interacción para rastrear la lengua del niño durante las sesiones. Basé el marco teórico en la distinción de Vygostsky entre conceptos cotidianos y científicos y su teoría del juego. Observé que los contextos de interacción apoyaban al niño en el uso de ciertas palabras en asociación con otras. En particular, empezó a relacionar las palabras grande y pequeño con números, por lo que cuantificó tamaños, lo cual es la fundamentación de la medida. De acuerdo con la importancia dada al habla por Vygotsky, pude rastrear el papel de las palabras en la progresión del niño desde conceptos cotidianos (de juego) hasta conceptos científicos (de matemáticas).

Palabras clave. Educación matemáticas en las primeras edades; aprendizaje a través del juego; conceptos cotidianos y científicos; lengua y matemáticas; Vygotsky.

\section{Introduction}

Early childhood mathematics has recently found its rightful place within mathematics education research. Björklund, van den Heuvel-Panhuizen and Kullberg (2015) explain that, in contrast to long-standing developmental and cognitive psychology research on early childhood, mathematics education research has a didactic perspective and deals explicitly with "the question of what the mathematics is in early childhood activities" (p. 608, original italics). Björklund et al. give a comprehensive overview of various aspects of early childhood mathematics that have captured researchers' interests. Studies might focus on what opportunities should be offered to young children, on understanding the mathematical thinking of a child, on how digital or other tools might be used to develop number sense, or on the design of interventions. 
Contemporary early childhood education promotes an informal pedagogy (see e.g. Wood \& Attfield, 2005; Duncan \& Lockwood, 2008) and a topic of interest in early childhood mathematics research is the balance between indirect and direct teaching. The latter may occur as a teacher interacts with children as they play or as they go about a variety of daily classroom activities. Drawing on Maier and Voigt's (1989) discussion about primary school mathematics, Vogler (2019) states that even in pre-school situations, there is a 'double layer structure' where the situational and concrete are superimposed with the mathematical abstract; hence, the teacher can take arising opportunities to teach mathematics indirectly. Weisberg, Kittredge, Hirsh-Pasek, Michnick Golinkoff and Klahr (2015) distinguish between three types of activities relevant to early childhood: Guided play, free play and teacher-instruction. Guided play is adult initiated but child directed. The adult might 'guide' indirectly by virtue of the structure of the environment s/he sets up -which will impose to a certain extent the direction of children's play- and/or by interacting directly with the children as they play. Weisber et al. (2015) cite several studies to argue that guided play appears to be more fruitful for young children's learning when compared to free play (child initiated and directed) or teacher instruction (adult initiated and directed). They also argue the balance between freedom and structure is what makes guided play such an effective tool.

A situation of guided play inevitably implies a level of interaction between the children and the teacher. Several studies have been carried out wherein researchers set a playful task for young children and then study the unfolding of the interaction and the attention to mathematical ideas (e.g. Björklund, 2016; Brandt, 2013; Breive, 2019; Sayers, Andrews, \& Björklund Boistrup, 2016; Tirosh, Tsamir, Levenson, \& Barkai, 2020; Vogler, 2019). Studies tend to be qualitative in nature, although Hundeland, Carlsen and Erfjord (2020) research uses a quantitative approach to analysing interactional characteristics in kindergarten classes. It is much less common to find studies carried out on play that is guided only by virtue of the play items provided. One exception is Helenius et al. (2016), who use play situations (6-year-old children playing with Lego ${ }^{\mathrm{TM}}$ blocks), to theorize about what renders play 'mathematical'.

Several studies on mathematics in early childhood settings adopt a sociocultural perspective, with the researchers considering learning as situational and interactional. Researchers may imply, or state explicitly, that they are adopting a Vygotskian perspective. Examples of such studies are Brandt (2013), Hundeland, Carlsen and Erfjord (2014), Vogel (2013), Walshaw (2017) and Worthington and van Oers (2016). The present paper, which is based on a study carried out in Malta, will also draw on Vygotsky. In my discussion of a four-year-old's play with loose parts, I use Vygotsky's distinction between everyday and scientific concepts, together with his theory of play. I focus on the use of the language -specifically speech- within the imaginary play situation. My intention is to use key ideas from Vygotsky's original (translated) texts to explore their relevance to contemporary early childhood mathematics education. This theorizing may shed further light on how children learn mathematics through play that is initiated and guided by an adult, but essentially directed by the child.

\section{Theoretical framework}

In this paper, I draw on three key points from Vygotsky's writing. The first is the notion of everyday and scientific concepts, the second is the great emphasis of this author on language (specifically speech), and the third is the important role he affords to children's play. 


\subsection{Everyday and scientific concepts}

Vygotsky (1987a) distinguished between 'everyday' and 'scientific' concepts (or 'spontaneous' and 'non-spontaneous' concepts. He argued that everyday concepts arise from a child's everyday experiences and that these are associated with "spontaneity, lack of conscious awareness, and the absence of a system" (1987a, p. 192). In contrast, scientific concepts involve generalisations and are associated with "conscious awareness and the presence of a system" (p. 191). It should be stated, however, that Nelson (1995) has proposed that the difference between everyday and scientific concepts be considered to lie in the kinds of generality and systems. She suggests that a young child's everyday concepts, rather than being unsystematic, are 'event representations', with boundaries, sequences of action, designated actors and objects. According to Nelson, the issue then is to coordinate and integrate the individual conceptual system with the culturally determined semantic system of abstract relations.

Vygotsky (1987a) believed that spontaneous and scientific concepts are related and constantly influence each other: A scientific concept depends on the spontaneous concept, but rests on generalisations and the establishment of hierarchical categories; in turn, the scientific concept influences the everyday concept that "acquires a whole series of new relationships with other concepts as it comes to stand between the scientific concept and its object" (p. 223). Wertsch (1985) explains that in the most advanced form of generalisation, that found in scientific concepts, the concept involves simultaneously two relationships: A relationship to an object and a relationship to another concept. For example, a child can not only use words like tables and furniture appropriately in connection with the objects to which they refer, but the child can also operate on statements of logical equivalence, non-equivalence, entailment and others, such as 'all tables are furniture'. Thus, the emphasis shifts away from those aspects of linguistic organisation that involve contextualisation, to the capacity of linguistic signs to enter into decontextualised relationships, that is, relationships which are constant across contexts (Wertsch, 1985).

According to Vygotsky (1987a), the move from spontaneous concepts to scientific concepts rests essentially on language, and scientific concepts develop mainly through direct (school) instruction, which allows the child to become reflectively conscious of their own mental processes. Wertsch (1985) elaborates that it is schooling's emphasis on using language to talk about language (that is, on decontextualised, metalinguistic reflection), that renders it an important force in the emergence of scientific concepts.

\subsection{The significance of speech}

Vygotsky's (1981a) reference to language as the most important psychological tool, or sign, is well known. He believed that language has the capacity to transform mental functioning and that, like other signs, it is "always originally a means used for social purposes, a means of influencing others, and only later becomes a means of influencing oneself' (1981a, p. 157). Indeed, he argued that what he considered to be 'higher mental functions'(including voluntary attention and memory, and rational, volitional, goaldirected thought) rely on the mediation of behaviour by sign and sign systems, the most important of which is speech (Minick, 1996). Ultimately, Vygotsky valued one of the organising principles of human language, namely, the capacity of words to enter into decontextualised relationships with other words (Wertsch, 1985). Vygotsky thus introduced the notions of the communicative and intellectual functions of speech (Wertsch, 1985). Wertsch outlines that this distinction builds on Vygotsky's general 
distinction between social and individual language use, considering more specifically the semiotic processes on the interpsychological and intrapsychological planes.

Minick (1996) highlights that a key development in Vygotsky's later work was his emphasis on the central function of word meaning as a means of communication, and therefore as a critical component of social practice. Initially, a word is an indicator, serving a referential function (Vygotsky, 1981b). The symbolic function of speech, on the other hand, involves the classification of events and objects in terms of generalised categories and eventually the formation of relationships among these categories (Wertsch, 1985). The development from referential to symbolic relates to word 'meaning', or concepts. Vygotsky identified 'word meaning' as an analytic unit. This is because he considered word meaning as a component of verbal thinking that contains thinking (i.e. generalisation) and speech in a functional relationship (Minick, 1996). Vygotsky claimed that by interacting with adults, children induce or infer the structure of concepts and word meanings that lie behind adults' speech and that this process is motivated by the need to define and redefine word meanings as a result of words being used in various contexts (Wertsch, 1985).

\subsection{Development through play}

As Kozulin (1996) explains, symbolism and the conventionality of signs were perceived by Vygotksy as important characteristics of human activity that shape an individual's behaviour; in the case of children, the actualisation of culture is embodied in the symbolic function of gesture, play and speech systems. Vygotsky (1967) gave importance to play in that he considered imaginary play to serve as a transitional stage between the immediate context to abstract thought. That is, it was through play that a child can "sever thought from an object" (p. 12). Vygotsky believed that the liberating of meaning from its origin in the perceptual field provides the foundation for the further development of speech and its role in advanced forms of thinking. According the interpretation inferred from Vygotsky (1967), this liberation of meaning from an object is facilitated by means of 'pivots.' For example, if a child uses a stick as a horse, the stick acts as a pivot to transition the child from a real situation to an imaginary one. While the child retains the property of the object, s/he changes its meaning. It is this new meaning that now becomes the central point and the object per se is moved from a dominant position to a subordinate one.

\subsection{Looking at early childhood settings through a Vygotskian lens}

The afore-mentioned tenets of Vygotsky's writings find great relevance in the early childhood school setting. The common periods of play during the school day offer a context for the child to learn and operate with everyday concepts. One type of play is that through which children use imagination to re-enact social situations (Wood \& Attfield, 2005). Using Nelson's (1995) perspective, the child here draws on certain types of generalities learnt in everyday situations. In this common kindergarten context, the teacher can take the role of a more-knowledgeable-other to influence the child's experiences and ideas through social interaction. One aspect of this influence can be to introduce children to school mathematics, while allowing the child to maintain the direction of their play. However, in this case, school instruction is not formal or direct, as implied in Vygotsky's writing, and therefore, the contexts within which everyday and scientific concepts are utilised and developed cannot be theoretically separated. Thus, I believe that the informal pedagogy setting of a kindergarten offers an interesting context 
to study the developing relationship between everyday and scientific concepts, and their developing interrelationship as realised through speech.

\section{Research design}

My study was carried out in a kindergarten in Malta. The aim of the study was to first observe children playing without adult intervention, to see if, and how they would engage with mathematical ideas. In the second part of the study, I used the play context to encourage children to attend to mathematical ideas, mainly number and counting. I presented the four participating children with 'loose parts' to play with- acorns, sea shells, coloured gems, blocks, connecting camels, pebbles, and so on. The play was thus guided by virtue of the items available. For the first five sessions, I mainly observed the children, keeping interaction with them to a minimum. In this first part of the study, the four children played altogether. For the second part of the study, (three sessions), I planned to interact with the children frequently by talking to them about their play, prompting them to count and so on. The intention here was for me to take the role of a 'responsive' adult, following Stacey's (2009, p. 14) recommendation: "Join the children in play and engage in authentic conversations with them". During this phase the children were intended to be taken in pairs to maximise interaction. However, one of the girls left the school unexpectedly, so she did not participate in the second part of the study. Hence, the remaining two girls were paired while the boy was taken alone. This child, whom I call Mario, is the subject of this paper.

The play sessions were held in the school library, which had a large open space where the play tables could be set up and where the children could also play comfortably on the carpet and couch. The sessions were video-recorded and generally lasted about 25 minutes. English was used for communication since this was the lingua franca of their classroom. It should be pointed out that using English for communication is common in Maltese classrooms wherein several nationalities or language groups are represented. In fact, one of the participants of this study was Hungarian, one was Chinese, while two, including Mario, were Maltese. All four could understand English well, and could also communicate in English, albeit with different levels of proficiency. I chose to continue the second part of the study with Mario in English too, even though his home language was Maltese. This was so that this aspect of the study would remain constant across the settings, for comparison purposes.
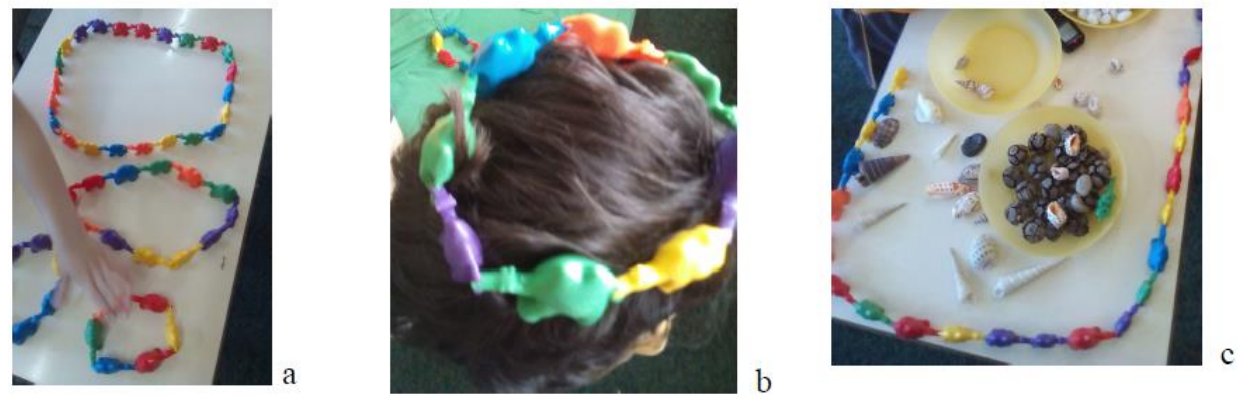

Figure 1. Bracelets, necklaces and crowns (a \& b) and decorations (c) with connecting camels

The children were attracted to the loose parts and enjoyed using them as part of their imaginative narratives. Throughout the sessions, a recurrent play theme was birthday parties, a theme initiated in the first session by one of the girls. The children repetitively made cakes (using plastic dishes and the loose parts as ingredients and candles), invited guests (represented by picture cards) and so on. The children also made crowns, necklaces and party decorations with the connecting camels as shown in Figure 1(a-c). 
Mario was particularly drawn to the camels and, when taken alone, played almost exclusively with them.

The analysis presented in this paper builds on previous discussions. In Farrugia (2019), I analysed the children's talk during the first part of the study, noting how the four children focused almost exclusively on imaginative narratives, and hardly ever used mathematics in their play. In Farrugia (2021), I used Sfard (2008)'s definition of discourse to analyse the paired girls' play in terms of four constituting elements: words, endorsed narratives, routines and visual mediators. In Farrugia (2020), I reflected on the corpus of data pertaining to Mario's individual play, once again using Sfard (2008) as an interpretative framework. The importance of using a wider definition of discourse is that the development of meaning is a result not only of language alone. However, in this paper I wish to focus on speech, in order to try to understand more specifically its influence on the development of mathematical ideas. Following Vygotsky, Wertsch and Stone (1985) state that internalisation is the process of gaining control over external sign forms. In my analysis, I consider words as external sign forms, and their association as evidence of gaining control. Thus, the micro-analysis undertaken takes the assumption that, "Words gather meanings from 'the company they keep' -i.e. from the influence of the meanings of other words which are used with them" (Mercer, 2000, p. 67).

\section{Discussion of data}

During the five sessions when Mario and the other children played without adult interaction, I observed that much of their talk referred to what they were making and the items they were using (Farrugia, 2020). For example, Mario told me, "Miss, look! This is a crown", "Miss, I'm going to play with the shells. I need the 'carrot' one. It looks like a carrot. I don't know where it is". Mario used the words big and some on three occasions, for example when addressing another child: "Sarah, now I'll make a big one, so we'll have a big crown for us ... wow, a big crown", "Sarah, look at my big crown ready", "Look, I made a big crown" and "Let's make a big party". Mario's use of the word big confirmed the suggestion by Montague-Smith, Hansen, Cotton and Price (2018) that children aged 3 to 4 years use one of three standards to judge size: perceptual (what the object looks or feels like), normative (comparing it with a mental image of what is 'normal') and functional (comparing it with what it is used for). For example, a crown may have been too large to sit on a head (function) and it looked more like a necklace (perceptual); the party was big in the sense that several birthday cakes were to be made (normative). Thus, I consider that here Mario was participating on the concrete, situational level (Vogel, 2019). The word big was not used in explicit association with other words that express quantity or comparison. With regard to the word some, Mario used it to express a need for play items; one instance was when the other children had monopolized the shells and Mario demanded "Give me some!" Another instance was when he couldn't find the camels: "I'm going to need some camels. Where ARE these camels?!" Hence, the word some was used to express a need for items to play with, rather than in relation to a specific quantity. Quantifying size is a foundational idea of measurement, so at this stage I concluded that Mario was not actually engaging with the mathematical idea of 'measurement'.

In the second part of the study, I interacted with Mario as he continued to direct the play with his favourite camels. The main aim for my input was to prompt him to use counting during his play. I did this by introducing the key phrase how many? which prompted Mario to recite the counting numbers and tag items correctly up to ten, and inaccurately beyond that. This reflected the number work being carried out as part of the 
classroom curriculum since the children were learning number recognition and counting, mainly up to ten. However, Mario's interest in creating big crowns presented an opportunity for linking counting with size, and thus an introduction to measurement. It is on this aspect of the conversations that I focus in this paper. The following excerpts show the development of talk over the three days; for the purpose of conciseness, some speech is omitted in the transcripts. This is indicated by [...].

On Day 1 of the second part of the study, the first day when Mario was taken alone, he went straight for his favourite camels to create various circuits. I did not interfere with this interest, but found the opportunity to build on the idea of (functional) size (i.e. a crown that fits) that he had brought up in the previous sessions. Key word associations to be noted in the following interaction are big/bigger/fit/some left/more/no more.

Mario: (Empties a bucket of camels and starts connecting) I can make a BIG crown.

MT: Do you remember how many camels you used yesterday?

Mario: Yes, a lot. (Creates a circuit of 6 camels) I did it! It's a bracelet.

MT: $\quad$ So how many camels did you have to use to make it?

Mario: (Touches each camel in turn) One, two, three, four, five, SIX.

MT: $\quad$ Six camels! I wonder if you can make it a bit bigger, to fit ME.

Mario: Yes.

MT: $\quad$ What shall we do to make it a bit bigger?

Mario: MORE camels. We can make different colours. (Creates another circuit)

MT: $\quad$ That's fine. Do you think that will fit me? How many camels did you have to use to make one for me?

Mario: (Counts, touching the camels in turn) One, two, three, four, five, six, seven, EIGHT.

MT: Eight! Let's see ... Does it fit me?

Mario: (Slips the 'bracelet' over MT's hand. The bracelet hangs loose over MT's wrist. Mario and MT laugh)

$[\ldots]$

Mario: (Works on a new circuit) It's coming big!

MT: Wow! I think it's a bracelet for a giant! (Touches her wrist) It's too big for $M E !$

Mario: That one's a big crown, for my head. My head is very big. (Touches his head)

MT: Ooh! (Passes a camel to Mario) You've got some left. (Referring to the camels which Mario was using)

Mario: Yes. There's two... (Connects one camel) Now there's one. (Takes the last one) Took it!

MT: How many left?

Mario: No, there're no more.

On Day 2, I latched onto the birthday theme once again, asking Mario to make a party for my friend's new baby. Through the interaction, we continued to link quantity with size through similar words as Day 1, but as can be seen towards the end of the excerpt, Mario now started spontaneously to associate number with size, albeit still in 
collaboration with me. (Key associations: twenty-lot-longer-big of hundred). (Note: with hindsight, I cannot recall exactly why I used the word hundred for 'many', but in an earlier session Mario had spontaneously used the word million for this purpose, so I might have been influenced by this previous incident).

Mario: Miss, now we're going to put the camels on the floor to make the floor a decoration.

MT: Do you think you'll need many of them or just of few?

Mario: Many, because the table is very big. (Nods in the direction of the table. He picks out a string of already connected camels from the bucket) I found a big line here. Big line, full of camels.

$[\ldots]$

MT: (Mario is creating a long circuit of camels that is intended to go around the four legs of the table. MT offers to help Mario by connecting short strings of camels) How many shall I join up?

Mario: Many.

MT: D'you know how many?

Mario: Twenty. (Up to now the line of camel goes around two table legs)

MT: $\quad$ Ah, twenty.

Mario: Twenty's a LOT.

MT: (Hands Mario a string of eight camels) Can you place those? Do you think we've got twenty up to now?

Mario: No, it needs longer. (Attaches the eight camels to the long string on the carpet) Look, we have to make it a bit longer.

MT: $\quad$ I wonder if we need a hundred.

Mario: Yes, we need big of hundred. $[\ldots]$

MT: (The circuit around the table legs is almost complete, but had to be continued with blocks after Mario ran out of camels) I'm going to help you. (Hands a stick of nine blocks to Mario) Is that enough?

Mario: Yes, I think. (Takes the stick of blocks)

MT: Is it enough or not?

Mario: (Connects another block to the stick) Yes. Some more.

MT: $\quad$ Some more?

Mario: Yes. So it can be a bit longer.

On Day 3, Mario made the connection between size and quantity himself, and seemed to draw on an incident that had occurred towards the end of the fifth session, when the children had been playing together. On that day, Mario had made a bracelet for himself with four camels, which however did not fit around his wrist, and it had disconnected. Mario had asked me if I could close it, and I had commented "I think you need an extra one [camel]. I think you need another one". Mario had added a camel and the bracelet had fitted well. In the excerpt below, it can be seen that Mario appeared to remember this incident and repeated the action done previously. 
Mario: (He has made a 'bracelet' with 6 camels. MT asks him if he can make a bracelet with ten camels) I can make a crowns [sic] with ten ...

MT: $\quad$ Yeah. Maybe it could be a crown not a bracelet. Maybe it would be too big to be a bracelet.

Mario: I'm gonna make a bracelet AND a crown.

MT: $O K$.

Mario: (Starts connecting camels quietly) Maybe I need to put [make] the bracelet a bit bigger. Maybe there are more camels than they [sic] thought. (Continues connecting camels) I did some more.

$[\ldots]$

Mario: (He has made another circuit of camels and places it on his head)

MT: Wow. How sweet.

Mario: No, it's small. It's not a bit fitting. (Removes the crown) I need to make it a bit bigger. (Disconnects two camels and adds another one in between)

MT: How many extra ones are you putting in?

Mario: Some more. I need to make it a bit bigger. (Adds three more camels. Picks it up, smiles at MT, and places it on his head. The crown slips over his head and hangs around his neck. He smiles)

Towards the end of the session Mario spontaneously talks about his bracelet and crown by quantifying their size:

MT: How nice! Wow, how many are there, THERE? (Referring to the crown)

Mario: I made a big one, ten. (Points to the previously made bracelet) Now I made a big one with twenty.

MT: Is that twenty?

Mario: Yes!

MT: Would you like to count them?

Mario: No, cos I SAID twenty.

For Mario, 'twenty' represented a large number, irrespective of whether the quantity was, in fact, exactly 20 or not. Since I had already realised this, it was not an issue that Mario was here using this number to describe the number of camels inaccurately. Rather, I considered this last part of conversation as very significant: Mario was now associating the length of a circuit with a specific number and associating the words big and ten/twenty [camels].

\section{Conclusion}

A number of reflections may be drawn from this case study. My role as teacherresearcher highlights the importance of the role of a guiding adult, illustrating Vygotsky's strong belief in the adult role as a guide who can support a child to appropriate cultural elements within social contexts. Over the days, Mario not only reacted willingly to my prompts to count and to attend to my own quantifying of size but, in the end, he did this himself without prompting. This development can be summarised as follows: 
- Mario gives a qualitative interpretation to his play items; e.g "the crown is big" because it drops over his head -here the comment is based on the crown's function, and there is no explicit quantification in relation to size.

- Mario counts the camels, generally correctly, in response to my asking how many. "One, two, three, etc."

- Mario associates the counting numbers with size: "I made a big one, ten", "We need big of hundred."

Van Oers (2010) explains that an unintentional, or spontaneous, action/utterance by a child may be taken as a cultural form (for example, mathematics) and reacted to accordingly by an adult. In time, through participation in such interactions, the child may acknowledge the (mathematical) meaning of the adult reaction, and finally, of his/her own actions as well. Indeed, through interaction, Mario began to include mathematics in his play, in the sense that he started using language in a new way. While my original plan had been to encourage counting, the play context that he himself had shaped, offered an opportunity for counting to be linked with size. As stated earlier, quantifying size is a foundational idea of measurement.

The shifting of a child's thought from the imaginative narrative to thinking about the play in a mathematical way, requires the play items to be momentarily afforded a different role. Vygotsky (1967) considered a play item as a 'pivot' that allows the child to from a real situation to an imaginary one. As I have argued in Farrugia (2019), the camels served as a 'dual pivot'; for the imaginary purpose of party decoration, and as items for mathematical abstraction.

The interweaving of the ideas related to the imaginative play (wearing crowns, making party decorations and so on) with mathematics-related ideas offered an illustration of the interweaving of everyday and scientific concepts. As stated by Vygotsky (1987, p. 219) "these processes are internally and profoundly connected with one another". This close connection is very relevant to the informal pedagogy approach promoted for contemporary early childhood education, wherein 'instruction' is not separate from everyday activities, including play.

A common thread ran throughout the sessions since Mario's drew on play carried out on previous days. In particular, he recalled the incident of the bracelet that did not fit and had needed an extra camel to be added in. He used the same solution to extend a circuit and used relevant words as he did so. According to Vygotsky (1987b), memory is the dominant function in early childhood, and it defines thinking. This implies that a continuity of thought may serve a key role in early childhood settings, so that a play setting that is repeated may be a useful context within which ideas can be developed. Perhaps the frequent clearing up of playthings that occurs in our kindergarten classrooms may be serving to interrupt potentially helpful trains of thought over the day/s!

This case study allowed me to carry out an in-depth analysis of the interaction between an adult and a child during play that, although adult initiated by virtue of the play items prepared by the adult, was nonetheless child directed. In my role as a teacher, I found the experience enjoyable and rewarding; it also allowed me to appreciate the challenge a kindergarten teacher faces to 'add depth' to play situations. After all, I had the luxury of interacting in detail with just one or two children at one time, and with mathematics as a main focus. A regular kindergarten teacher has more children to deal with and other learning areas s/he might wish to address, such as literacy, science, aesthetics and social skills. In my role as researcher, I have offered an application of 
Vygotsky's original tenets as one way of interpreting young children's development of mathematical ideas. This is important since learning in early childhood settings is quite different to the direct instruction found in later primary school years. An interpretation of how everyday concepts can develop -through speech- into scientific concepts, can help us understand in more detail how to maximise children's learning of mathematics in informal settings.

\section{References}

Björklund, C. (2016). Playing with patterns: conclusions from a learning study with toddlers. In T. Meaney, O. Helenius, M. L. Johansson, T. Lange, \& A. Wernberg (Eds.), Mathematics education in the early years (pp. 269-287). Dordrecht, Netherlands: Springer.

Björklund, C., van den Heuvel-Panhuizen, \& Kullberg, A. (2020). Research on early childhood mathematics teaching and learning. ZDM-Mathematics Education, 52, 607-619.

Brandt, B. (2013). Everyday pedagogical practices in mathematical play situations in German 'kindergarten'. Educational Studies in Mathematics, 84, 227-248.

Breive, S. (2019). Kindergarten teachers' orxchestration of mathematical learning activities: the balance between freedom and structure. In U. T. Jankvist, M. van de Heuvel-Panhuizen, \& M. Veldhuis (Eds.), Proceedings of the $11^{\text {th }}$ Congress of the European Society for Research in Mathematics Education (pp. 2241-2248). Utrecht, Netherlands: Freudenthal Group \& Institute and ERME.

Duncan, J., \& Lockwood, M. (2008). Learning through play: A work-based approach for the early years professional. London, Enngland: Continuum.

Farugia, M. T. (2021). Mathematics through play. The influence of adult intervention on young children's shifts between play and mathematical discourses. In N. Planas, C. Morgan, \& M. Schütte (Eds.), Classroom research on mathematics and language: Seeing learners and teachers differently (pp. 134-150). London, England: Routledge.

Farrugia, M.T. (2020). Toys as dual pivots for imaginative play and mathematics. In J. Ingram, K. Erath, F. Rønning, \& A. K. Schüler-Meyer (Eds.). Proceedings of the European Research on Mathematics Education Topic Conference on ClassroomBased Research and Mathematics and Language (pp. 97-104). Montpellier, France: University of Montpellier \& ERME.

Farrugia, M. T. (2019). Young children's mathematising during free play with 'loose parts'. In U. T. Jankvist, M. van de Heuvel-Panhuizen, \& M. Veldhuis (Eds.), Proceedings of the $11^{\text {th }}$ Congress of the European Society for Research in Mathematics Education (pp. 1640-1647). Utrecht, Netherlands: Freudenthal Group \& Institute and ERME.

Helenius, O., Johansson, M.L., Lange, T., Meaney, T., Riesbeck, E., \& Wernberg, A. (2016). When is young children's play mathematical? In T. Meaney, O. Helenius, M. L. Johansson, T. Lange, \& A. Wernberg (Eds.), Mathematics Education in the early years (pp. 139-156). Dordrecht, Netherlands: Springer.

Hundeland, P. S., Carlsen, M., \& Erfjord, I. (2014). Children's engagement with mathematics in kindergarten mediated by the use of digital tools. In U. Kortenkamp, B. Brandt, C. Benz, G. Krummheuer, S. Ladel, \& R. Vogel (Eds.), Early 
Mathematics Learning: Selected Papers of the POEM2012 Conference. Dordrecht, Netherlands: Springer.

Hundeland, P. S., Carlsen, M., \& Erfjord, I. (2020). Qualities of mathematical discourses in kindergartens. ZDM-Mathematics Education, 52, 691-702.

Kozulin, A. (1996). The concept of activity in Soviet pyschology: Vygotsky, his disciples and critics. In H. Daniels (Ed.), An Introduction to Vygotsky (pp. 99-122). London, England: Routledge.

Maier, H., \& J. Voigt. (1989). Die entwickelnde Lehrerfrage im Mathematikunterricht, Teil 1. Mathematica Didactica, 12 (1), 23-55.

Mercer, N. (2000). Words and minds: How we use language to think together. London, England: Routledge.

Minick, N. (1996). The development of Vygotsky's thought: An introduction to Thinking and Speech. In H. Daniels (Ed.), An Introduction to Vygotsky (pp. 28-52). London, England: Routledge.

Montague-Smith, A., Cotton, T., Hansen, A., \& Price, A. J. (2018). Mathematics in Early Years Education (4th ed.). London, England: Routledge.

Nelson, K. (1995). From spontaneous to scientific concepts: Continuities and discontinuities from childhood to adulthood. In L. Martin, K. Nelson, \& E. Tobach (Eds.), Sociocultural psychology: Theory and practice of doing and knowing (pp. 229-249). Cambridge, England: University Press.

Sayers, J., Andrews, P., \& Björklund Boistrup, L. (2016). The role of conceptual subitising in the development of foundational number sense. In T. Meaney, O. Helenius, M. L. Johansson, T. Lange, \& A. Wernberg (Eds.), Mathematics education in the early years (pp. 371-394). Dordrecht, Netherlands: Springer.

Sfard, A. (2008). Thinking as communication: Human development, the growth of discourses, and mathematising. Cambridge, England: University Press.

Stacey, S. (2009). Emergent curriculum in early childhood settings. St. Paul, MN: Redleaf.

Tirosh, D., Tsamir, P., Levenson, E. S., \& Barkai, R. (2020). Setting the table with toddlers: A plyaful context for engaging in one-to-one correspondence. ZDMMathematics Education, 52, 717-728.

Van Oers, B. (2010). Emergent mathematical thinking in the context of play. Educational Studies in Mathematics, 74, 23-37.

Vogel, R. (2013). Mathematical situations of play and exploration. Educational Studies in Mathematics, 84, 209-225.

Vogler, A-M. (2019). Chances and obstacles of 'indirect' learning processes in situations with preschool teachers. In U. T. Jankvist, M. van de Heuvel-Panhuizen, $\&$ M. Veldhuis (Eds.), Proceedings of the $11^{\text {th }}$ Congress of the European Society for Research in Mathematics Education (pp. 2389-2396). Utrecht, Netherlands: Freudenthal Group \& Institute and ERME.

Vygotsky, L. S. (1967). Play and its role in the mental development of the child. Soviet Psychology 5(3), 6-18. 
Vygotsky, L. S. (1981a). The genesis of higher mental functions. In J. Wertsch (Ed.), The concept of activity in Soviet psychology. Armonk, NY: M.E. Sharpe.

Vygotsky, L. S. (1981b). The development of higher forms of attention in childhood. In J. Wertsch (Ed.), The concept of activity in Soviet psychology. Armonk, NY: M.E. Sharpe.

Vygotsky, L. S. (1987a). The development of scientific concepts in childhood (Thinking and Speech Chapter 6). In R. W. Reiber, \& A. S. Carton (Eds.). The Collected Works of L. S. Vygotsky, Volume 1 (pp. 167-241). New York: Plenum Press.

Vygotsky, L. S. (1987b). Memory and its development in childhood. In R. W. Reiber, \& A. S. Carton (Eds.). The Collected Works of L. S. Vygotsky, Volume 1 (pp. 303310). New York: Plenum Press.

Walshaw, M. (2017). Understanding mathematical development through Vygotsky, Research in Mathematics Education, 19(3), 293-309.

Weisberg, D., Kittredge, A. K., Hirsh-Pasek, K., Golinkoff, R. M., \& Klahr, D. (2015). Making play work for education, Phi Delta Kappan, 96(8), 8-13.

Wertsch, J. V. (1985). Vygotsky and the social formation of mind. Cambridge, MA: Harvard University Press.

Wertsch, J. V., \& Stone, C. A. (1985). The concept of internalisation in Vygotsky's account of the genesis of higher mental functions. In J. V. Wertsch (Ed.), Culture, communication and cognition: Vygotskian perspectives (pp. 162-182). New York: Cambridge University Press.

Wood, E., \& Attfield, J. (2005). Play, learning and the early childhood curriculum. London, England: Paul Chapman.

Worthington, M., \& van Oers, B. (2016). Pretend play and the cultural foundations of mathematics. European Early Childhood Education Research Journal, 24(1), 5166.

\section{Author's contact details}

Marie Therese Farrugia, University of Malta (Malta).marie.t.farrugia@um.edu.mt 


\title{
From everyday to scientific (mathematical) concepts: A Vygotskian interpretation of a young child's speech
}

\author{
Marie Therese Farrugia, University of Malta
}

In Early Childhood settings, children are assumed, and expected, to learn through play. The pedagogy used in kindergartens is often an informal one, where an adult interacts with children as they play or carry out daily tasks. In this paper I report on a case-study of a four-year-old boy playing with loose parts (pebbles, acorns, blocks, shells, connecting camels, and so on). The play was 'guided' in the sense that the play items were provided, but beyond this, the play was child-directed. As the child played, I interacted with him by commenting and asking questions. The aim of my involvement was to include mathematics in his play. In particular, I wished to prompt the child to count and attend to quantity. The theoretical framework employed was Vygotsky's distinction between everyday and scientific concepts, and his emphasis on speech for the development of concepts. I also drew on his theory of play. The play sessions were carried out in a comfortable library, and were video-recorded. For the first five sessions, the child played with other children and I kept my intervention with them to a minimum. For the last three sessions, the child's sessions were individual. His favourite play item was the set of connecting camels and he repeatedly made circuits which he referred to as crowns and bracelets. My analysis involved a micro-examination of the interaction between us to explore if, and how, the child's own use of language developed over the sessions. Apart from responding to my prompts to count, which he did accurately up to ten, I noted that the child to begin to use certain words in association with others. In particular, he started to link the words big/small with numbers and thus began to quantify size, which is the foundation of measurement. Thus, in line with the importance afforded to speech by Vygotsky, I was able to trace the role played by words in the child's progression from everyday (play) concepts to scientific (mathematical) concepts. My study offers a focus on children as they play freely, since most research in the early childhood context tends to be based on researcher-designed tasks, rather than on childdirected play. Furthermore, although play with loose parts is a common activity in kindergartens, it is a novel topic of research. In this paper, I offer an application of Vygotsky's original tenets as one way of interpreting young children's development of mathematical ideas. This is important since learning in early childhood settings is quite different to the direct instruction found in later primary school years. An interpretation of how everyday concepts can develop -through speech- into scientific concepts, can help us understand in more detail how to maximise children's learning of mathematics in informal settings. 